\title{
Prenatal Therapy of Large Placental Chorioangiomas: Case Report and Review of the Literature
}

\author{
Pardis Hosseinzadeh, MD ${ }^{1}$ Alireza A. Shamshirsaz, MD ${ }^{1,3}$ Pouya Javadian, MD ${ }^{1} \quad$ Jimmy Espinoza, MD ${ }^{1,4}$ \\ Manisha Gandhi, MD ${ }^{1}$ Rodrigo Ruano, MD, PhD ${ }^{1,3}$ Darrell L. Cass, MD ${ }^{2}$ Oluyinka A. Olutoye, MD ${ }^{2}$ \\ Michael A. Belfort, MD, PhD ${ }^{1,3}$
}
${ }^{1}$ Division of Maternal Fetal Medicine, Department of Obstetrics and Gynecology, Baylor College of Medicine and Texas Children's Hospital, Houston, Texas
2 Division of Pediatric Surgery, Texas Children's Fetal Center and Michael E. DeBakey Department of Surgery, Baylor College of Medicine, Houston, Texas
${ }^{3}$ Division of Fetal Intervention, Department of Obstetrics and Gynecology, Baylor College of Medicine and Texas Children's Hospital, Houston, Texas
${ }^{4}$ Division of Women's and Fetal Imaging, Department of Obstetrics and Gynecology, Baylor College of Medicine and Texas Children's Hospital, Houston, Texas
Address for correspondence Alireza A. Shamshirsaz, MD, Texas Children's Fetal Center and the Department of Obstetrics and Gynecology, Baylor College of Medicine, Houston, TX 77030 (e-mail: alirezashamshirsaz@yahoo.com; shamshir@bcm.edu).

Am J Perinatol Rep 2015;5:e196-e202.

\begin{abstract}
Keywords

- chorioangioma

- laser ablation

- nonimmune hydrops fetalis

- systematic review
\end{abstract}

Objective To review techniques and outcomes of different prenatal treatments for large placental chorioangiomas.

Study Design Presentation of a case of laparoscopic-assisted laser coagulation and a systematic review of the literature for articles related to intervention for placental chorioangioma.

Results A total of 37 cases of definitive $(n=23)$ and supportive therapy $(n=14)$ were evaluated, including one case treated in our center. Approximately $35 \%$ of the patients had a spontaneous preterm delivery in definitive treatment group versus $36 \%$ in the supportive group. The infant survival rates were 65 and $71 \%$ in the two groups, respectively. We further compared the two types of laser ablation (fetoscopic $[n=10]$ and interstitial $[n=4])$. Approximately $30 \%$ of the patients in the fetoscopic and $25 \%$ in interstitial group, had a spontaneous preterm delivery. Survival rates were 60 and $100 \%$ in fetoscopic and interstitial groups, respectively.

Conclusion Laser ablation and embolization of chorioangiomas via minimally invasive approach may prevent or reverse fetal hydrops due to high cardiac states. However, further studies are needed to refine the appropriate selection criteria that will justify the risk of this invasive in utero therapy for chorioangiomas. received

May 11,2015

accepted after revision

June 4, 2015

published online

August 3, 2015
DOI http://dx.doi.org/

10.1055/s-0035-1558829.

ISSN 2157-7005.
Copyright $\odot 2015$ by Thieme Medical

Publishers, Inc., 333 Seventh Avenue,

New York, NY 10001, USA.

Tel: +1(212) 584-4662.
License terms

(c) (1) $\ominus$ (\$) 


\section{Background/Objectives}

The vast majorities of placental chorioangiomas are asymptomatic and usually escape clinical and sonographic detection, especially those measuring less than $4 \mathrm{~cm}$ in diameter. In contrast, those larger than $4 \mathrm{~cm}$, although rare, are associated with adverse perinatal complications. The most common complications are polyhydramnios, premature delivery, nonimmune hydrops fetalis, fetal disseminated intravascular coagulopathy, fetal anemia, and thrombocytopenia, highoutput congestive heart failure, and growth restriction with an overall perinatal mortality of approximately 30 to $40 \%{ }^{1-4}$ Polyhydramnios and fetal anemia secondary to these tumors have been treated with therapeutic amnioreduction and intrauterine blood transfusion., ${ }^{5,6}$ Various other therapeutic strategies have been reported; including endoscopic-guided ligation of vessels, percutaneous interstitial laser, microcoil embolization, and endoscopic laser coagulation, ${ }^{5-10}$ with conflicting results. We report our recent experience in the evaluation and treatment of a large placental chorioangioma associated with signs of fetal cardiac failure, and provides a systematic literature review of available cases that underwent intervention.

\section{Data Sources}

This article comprises a case report, a review of the literature (performed in accordance to the STROBE/MOOSE guidelines) 11,12 and a statistical analysis of data extracted from the literature search in addition to our case. Two of the authors independently performed literature searches in online databases (PubMed, Ovid, and MEDLINE) for articles related to chorioangioma between 1965 and 2014. Only English language publications were selected. The reference lists of the articles identified were examined for potential additional pertinent references.

The following information was extracted: gestational age (at time of diagnosis, procedure, and delivery), fetal ultrasound findings, type of intervention, and the surgical details, obstetric and procedural complications (intrauterine death, hemorrhage, premature preterm rupture of the membranes and spontaneous preterm ( $<37$ weeks of gestation delivery), and perinatal and neonatal outcome, and where available long-term survival rates. It was acknowledged that there might be limitations to the case collection due to publication bias.

\section{Results}

\section{Case Report}

A 30-year-old, gravida 3, para 1 was seen at the Texas Children's Hospital Fetal Center for early ultrasound at 16 weeks' gestation and a $3 \mathrm{~cm}$ placental chorioangioma was noted. The patient was followed up at $20^{3 / 7}$ weeks of gestation at which time the placental chorioangioma had increased to $6 \mathrm{~cm} \times$ $5 \mathrm{~cm} \times 2.5 \mathrm{~cm}$ with no evidence of cardiomegaly, tricuspid or mitral regurgitation, fetal ascites, or hydrops. At $21^{5 / 7}$ weeks' gestation cardiac dysfunction was detected with elevated combined cardiac output measured at $635 \mathrm{~mL} / \mathrm{min} / \mathrm{kg}^{13}$
The fetal middle cerebral artery peak systolic velocity was within the normal range and there was no polyhydramnios, but given the rapid onset of significantly elevated cardiac output the baby was deemed to be at risk for cardiac failure and death.

The chorioangioma was located within $1 \mathrm{~cm}$ of the cord insertion site, and was connected to the umbilical cord confluence by surface feeder vessels with a diameter of about $2.5 \mathrm{~mm}$. There were no identified deep feeder vessels visible on three-dimensional ultrasound.

After extensive prenatal counseling, and approval from the fetal therapy board, the patient was offered and accepted intervention with fetoscopic laser ablation of the chorioangioma at $21^{6 / 7}$ weeks' of gestation. Due to a complete anterior placenta that precluded direct access, a laparoscopic-assisted fetoscopic approach via the right lateral-posterior wall of uterus was used. Briefly, under general anesthesia, a small upper abdominal incision in the midline below the xiphosternum was made. Under direct laparoscope visualization, a second port was placed and used to elevate the uterus to allow the lateral side of the uterus to be exposed for insertion of the fetoscope. As we have described before, ${ }^{14}$ a $2.0 \mathrm{~mm}$ 0-degree fetoscope (11630AA, Karl Storz, Tuttlingen, Germany) was used.

A $600 \mu \mathrm{m}$ laser fiber and a Dornier Diode laser (D60 Multibeam Flexiplus; Dornier Medizintechnik, Wessling, Germany) set at 35 to $50 \mathrm{~W}$ were used to ablate the two main large diameter feeder vessels. Despite obvious occlusion of the two main feeder vessels, there was still some residual blood flow noted within the tumor. Further fetoscopic evaluation revealed additional smaller diameter vessels from more distal divisions of the placental circulation. Once these were ablated all flow to the chorioangioma ceased. A $200 \mathrm{~mL}$ amnioinfusion of lactated Ringer solution with nafcillin was required to allow adequate visualization of all vessels. The fetus tolerated the procedure well and there were no heart rate changes noted. The fetoscope and cannula were removed from the puncture site and a Gelfoam plug (Pfizer, New York, NY) was placed during the removal. There was no evidence of amnion-chorion separation or bleeding from the puncture site.

Follow-up ultrasound examination at $22^{4 / 7}$ weeks gestation an avascular placental mass which had decreased in size $(3.3 \times 5.6 \times 2.9 \mathrm{~cm})(-$ Figs. 1 and 2). Doppler studies (umbilical artery, middle cerebral artery, and ductus venosus) and cardiac function was normal. Fetal echocardiogram at $22^{4 / 7}$ weeks gestation showed a normal combined cardiac output of $485 \mathrm{~mL} / \mathrm{min} / \mathrm{kg} .^{13}$ At 39 weeks of gestation she presented in active labor with spontaneous rupture of membranes. The baby was born via spontaneous vaginal delivery with a weight of 3,476 $g$ and Apgar scores of 8 and 9 at 1 and 5 minutes. The mother and baby were discharged on postpartum day 2. - Fig. 3 shows the placenta and the chorioangiomas following laser ablation.

\section{Review of Literature Including our Case}

Our literature search revealed 14 cases of chorioangiomas treated with supportive management (5 with amnioreduction, 3 with intrauterine transfusion, and 6 with 

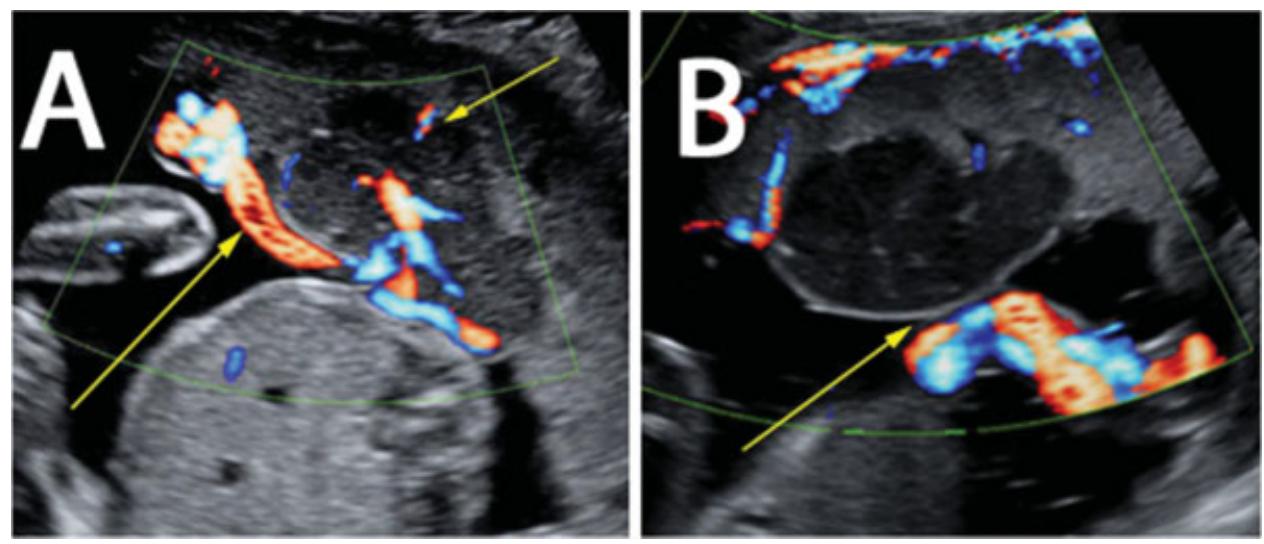

Fig. 1 Color Doppler image of feeding vessels of placenta (A) before and (B) after laser intervention.
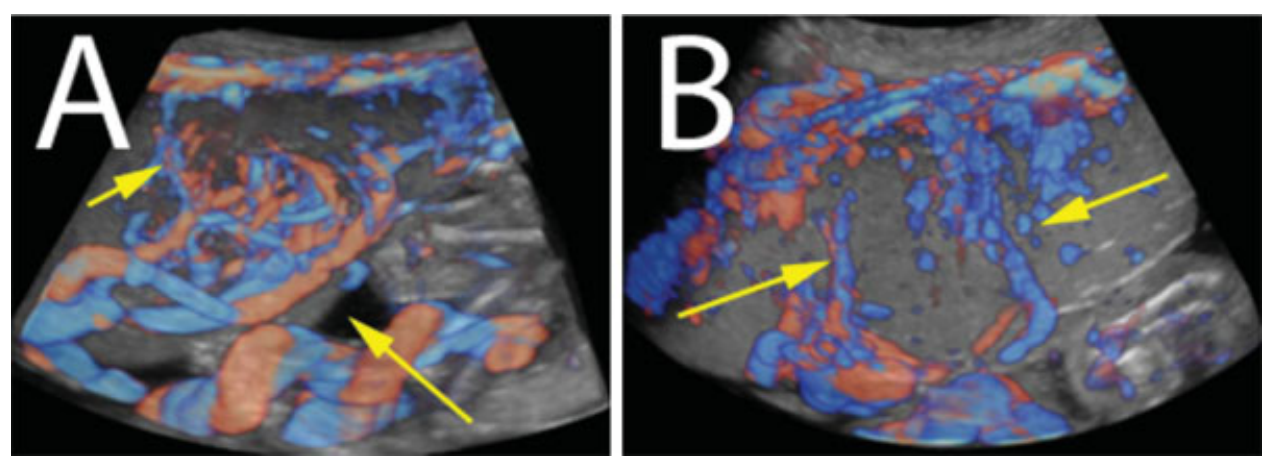

Fig. 2 Three-dimensional ultrasound image of vascularity of an involved area of placenta with chorioangioma. (A) Before and (B) after intervention.

transplacental pharmacotherapy [digoxin, indomethacin, and sulindac]). There were 23 cases treated using definitive therapy (10 had fetoscopic laser ablation [including our case], 4 had interstitial laser ablation under ultrasound guidance, 6 had alcohol injection, and 3 cases had embolization procedures) ( $\boldsymbol{- T a b l e} \mathbf{1}$ ). All of the data came from case reports or case series.

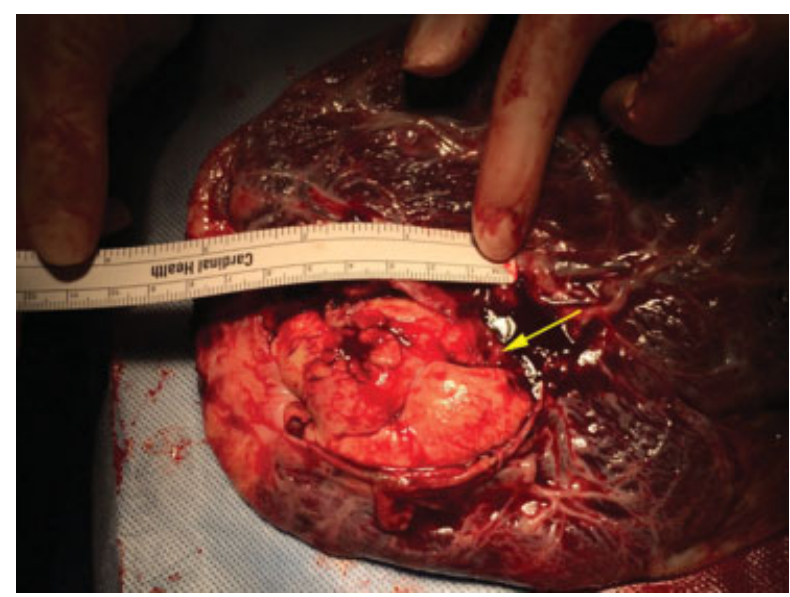

Fig. 3 Gross specimen showing placenta and the area of laser ablation for chorioangioma.
We collated the data and compared the definitive therapy and supportive treatment. Within the definite therapy group we compared the different type of laser ablation procedures (fetoscopic vs. ultrasound-directed interstitial ablation). Of the 23 cases that underwent occlusive therapy, 8 (35\%) experienced spontaneous preterm delivery versus 36\% in supportive group, a difference that is not statistically significant. The rate of survival was $65 \%$ in the definitive and $71 \%$ in the supportive group, respectively. Within the laser treatment group, approximately $30 \%$ of the fetoscopically managed patients, and $25 \%$ of those who had interstitial laser, had a spontaneous preterm delivery (non-significant, NS).The overall survival rate was $60 \%$ in the fetoscopic, and $100 \%$ in the interstitial group, respectively $(p=0.13)$. Gestational age at delivery was lower in the fetoscopic group versus the interstitial group $(35.2 \pm 3.5$ vs. $32.1 \pm 5.5, p=0.03$, respectively). Cases that underwent fetoscopic intervention showed a rate of polyhydramnios resolution of $62 \%$. Higher rate of polyhydramnios resolution (61\%) was seen in definitive therapy group in contrast with supportive therapy (30\%) but not in significant level $(p=0.36)$.

Five out of eight cases with polyhydramnios have resolved after fetoscopic intervention.

- Table 2 shows a summary and analysis of further demographic and outcome data. 
Table 1 Published chorioangioma therapy

\begin{tabular}{|c|c|}
\hline \multicolumn{2}{|l|}{ Supportive therapy $(n=14)$} \\
\hline \multirow[t]{3}{*}{ Amnioreduction $(n=5)$} & Bashiri, $1998^{28}(n=1)$ \\
\hline & Jauniaux and Ogle, $2000^{29}(n=3)$ \\
\hline & Sepulveda et al, $2003^{16}(n=1)$ \\
\hline \multirow[t]{3}{*}{ Intrauterine blood transfusion $(n=3)$} & Haak, $1999^{30}(n=1)$ \\
\hline & Hamill et al, $2003(n=1)$ \\
\hline & Esscribano, $2006^{31}(n=1)$ \\
\hline \multirow[t]{3}{*}{ Transplacental pharmacotherapy $(n=6)$} & Wang, $1996^{32}$ (digoxin) $(n=1)$ \\
\hline & $\begin{array}{l}\text { Zalel, } 2002^{33} \text { (digoxin }[n=2], \text { indomethacin }+ \text { digoxin }[n=1] \text {, } \\
\text { amniocentesis + digoxin }[n=1])\end{array}$ \\
\hline & Al Wattar et al, $2014^{24}$ (sulindac) $(n=1)$ \\
\hline \multicolumn{2}{|l|}{ Vascular occlusive Therapy $(n=23)$} \\
\hline \multirow[t]{2}{*}{ Interstitial laser ablation $(n=4)$} & Bhide et al, $2003^{7}(n=1)$ \\
\hline & Zanardini et al, $2010^{6}(n=3)$ \\
\hline \multirow[t]{8}{*}{ Fetoscopic laser ablation $(n=10)$} & Quintero et al, $1996^{10}(n=1)$ \\
\hline & Quarello et al, $2005^{9}(n=1)$ \\
\hline & Bermudez, $2007^{27}(n=1)$ \\
\hline & Sepulveda et al, $2009^{5}(n=3)$ \\
\hline & Mendez-Figueroa et al, $2009^{26}(n=1)$ \\
\hline & Zanardini et al, $2010^{6}(n=1)$ \\
\hline & Kathryn Jones, $2012^{34}(n=1)$ \\
\hline & Our case $(n=1)$ \\
\hline \multirow[t]{5}{*}{ Alcohol injection $(n=6)$} & Nicolini et al, $1999^{19}(n=2)$ \\
\hline & Jauniaux and Ogle, $2000^{29}(n=1)$ \\
\hline & Wanapirak et al, $2002^{23}(n=1)$ \\
\hline & Sepulveda et al, $2003^{16}(n=1)$ \\
\hline & Deren et al, $2007^{25}(n=1)$ \\
\hline \multirow[t]{2}{*}{ Embolization $(n=3)$} & Lau et al, $2003^{8}$ (microcoil and enbucrilate embolization) $(n=2)$ \\
\hline & Babic et al, $2012^{15}$ (enbucrilate embolization) $(n=1)$ \\
\hline
\end{tabular}

- Table 3 shows a categorization of the patients based on their survival. Tumor size at the time of intervention was smaller in the definitive management group than in the supportive group, but this did not reach statistical significance, possibly due to a type II error (54.1 \pm 14 vs. $71 \pm 13 \mathrm{~mm}, p=0.06)$. As expected, the rate of hydrops fetalis was higher in those babies that were lost when compared with those who survived (50 vs. $9 \%, p=0.05$ ). Premature preterm rupture of the membranes was significantly more common in the patients who experienced overall (fetal + neonatal) loss than in those with a surviving fetus (83.3 vs. $9 \%, p=0.002$ ).

\section{Discussion}

Approximately $50 \%$ of large (size $>4 \mathrm{~cm}$ ) placental chorioangiomas develop fetal and/or maternal complications that require either elective delivery or intervention for tumor- related effects. ${ }^{15} \mathrm{~A}$ chorioangioma may act as a peripheral arteriovenous shunt, leading to increased cardiac output, cardiomegaly, heart failure, and ultimately nonimmune hydrops. This may be complicated by fetal anemia in some cases. ${ }^{3,7,16-18}$ Experience with the fetoscopic treatment of placental chorioangiomas is limited. A total of 10 cases (including ours) of attempted endoscopic occlusion of feeder vessels of a chorioangioma have been reported to date ${ }^{19-23}$ with 6 (60\%) survivors. Our case is the first laparoscopically assisted laser ablation of chorioangioma reported, and this was necessary because complete anterior placentation precluded a standard percutaneous approach. The choice between fetsoscopic and interstitial laser ablation was made based on our overwhelmingly greater experience with the fetoscopic technique, the fact that the chorioangioma was very close to the cord insertion, and on personal communication with several international experts. The subsequent review of the literature does suggest equivalent, if not better, 
Table 2 Outcome of fetuses with chorioangioma that underwent definitive therapy versus supportive therapy and fetoscopic versus interstitial laser ablation of the tumor

\begin{tabular}{|l|l|l|l|l|l|l|}
\hline & $\begin{array}{l}\text { Definitive } \\
\text { therapy } \\
N=23\end{array}$ & $\begin{array}{l}\text { Supportive } \\
\text { therapy } \\
N=14\end{array}$ & $p$ Value & $\begin{array}{l}\text { Fetoscopic } \\
\text { laser } \\
N=10\end{array}$ & $\begin{array}{l}\text { Interstitial } \\
\text { laser } \\
N=4\end{array}$ & $p$ Value \\
\hline GA at diagnosis (wks), mean \pm SD & $23.3 \pm 2.8$ & $24.4 \pm 3.2$ & 0.55 & $23.1 \pm 0.5$ & $25.3 \pm 2.4$ & 0.63 \\
\hline GA at intervention (wks), mean \pm SD & $25.6 \pm 2.2$ & $25.5 \pm 2.1$ & 0.95 & $25.3 \pm 1.9$ & $25.6 \pm 2.18$ & 0.95 \\
\hline GA at delivery (wks), mean \pm SD & $32.2 \pm 5.0$ & $33.5 \pm 5.1$ & 0.85 & $32.1 \pm 5.5$ & $35.2 \pm 3.5$ & 0.03 \\
\hline $\begin{array}{l}\text { Tumor size at intervention (mm), } \\
\text { mean } \pm \text { SD }\end{array}$ & $65 \pm 18$ & $66 \pm 15$ & 0.12 & $63 \pm 15$ & $46 \pm 8$ & 0.23 \\
\hline Fetal anemia $N(\%)$ & $7(30 \%)$ & $3(21 \%)$ & 0.55 & $2(20 \%)$ & 0 & 0.33 \\
\hline Blood transfusion $N(\%)$ & $7(30 \%)$ & $3(21 \%)$ & 0.55 & $2(20 \%)$ & 0 & 0.33 \\
\hline Polyhydraminos resolution $N(\%)$ & $8 / 13(61 \%)$ & $3 / 10(30 \%)$ & 0.36 & $5 / 8(62 \%)$ & $0 / 0$ (No case) & Noncomparable \\
\hline Hydrops resolution $N(\%)$ & $1 / 7(14 \%)$ & $0 / 3(0 \%)$ & 0.46 & $0 / 2(0 \%)$ & $0 / 0$ (No case) & Noncomparable \\
\hline Amnioreduction $N(\%)$ & $3(13 \%)$ & $5(36 \%)$ & 0.11 & $2(20 \%)$ & 0 & 0.33 \\
\hline PPROM $N(\%)$ & $8(35 \%)$ & $5(36 \%)$ & 0.95 & $3(30 \%)$ & $1(25 \%)$ & 0.85 \\
\hline Neonatal survival $N(\%)$ & $15(65 \%)$ & $10(71 \%)$ & 0.69 & $6(60 \%)$ & $4(100 \%)$ & 0.13 \\
\hline
\end{tabular}

Abbreviations: GA, gestational age; PPROM, premature preterm rupture of membrane; SD, standard deviation.

outcomes with the interstitial approach and perhaps going forward this is something that deserves formal study. However, our systematic review does not conclusively demonstrate a benefit of treatment over conservative management in improving the fetal and neonatal mortality, a point that has previously been made by Al Wattar et al. ${ }^{24}$

The underlying problem leading to increased peripheral flow through a chorioangioma is intuitively not resolved with amniodrainage or fetal transfusion. Since the placenta is the area of lowest resistance in the fetal circulation, even a small chorioangioma can create a significant hemodynamic perturbation, and subsequent tumor growth may precipitate deterioration of the fetal cardiovascular status. Thus, any proposed treatment should ideally be targeted to arresting or at least diminishing the blood flow within the chorioangioma. Based on this reasoning several approaches have been employed to interfere with the vascular supply to the tumor and reverse fetal heart failure. These include the injection of absolute alcohol, ${ }^{23,25}$ embolization and fetoscopic intervention, $3,7,16,17$ endoscopic laser coagulation, ${ }^{7,26,27}$ and interstitial laser therapy. ${ }^{6,7}$ This case study and review of the literature allows a critical appraisal of the reported treatment options. Endoscopic laser ablation appears to be the most commonly used therapeutic modality although this may clearly represent a publication bias. While interstitial laser appears to have less complication, and may be more easily

Table 3 Prediction of survival after prenatal tumor laser ablation and embolization of the chorioangioma

\begin{tabular}{|l|l|l|l|}
\hline & Survived $N=11$ & Fetal loss $N=\mathbf{6}$ & $p$ Value \\
\hline GA at diagnosis (wks) & $22.2 \pm 4.2$ & $24.2 \pm 0.4$ & 0.02 \\
\hline Tumor size at intervention (mm) & $54 \pm 14$ & $71 \pm 13$ & 0.06 \\
\hline Fetal anemia N (\%) & $0(0 \%)$ & $3(50 \%)$ & 0.01 \\
\hline Polyhydramnios N (\%) & $5(45 \%)$ & $4(67 \%)$ & 0.40 \\
\hline Hydrops N (\%) & $1(9 \%)$ & $3(50 \%)$ & 0.05 \\
\hline Amnioreduction N (\%) & $1(9 \%)$ & $1(17 \%)$ & 0.46 \\
\hline GA at intervention (wks) & $25.6 \pm 2.2$ & $24.9 \pm 1.1$ & 0.08 \\
\hline GA at delivery (wks) & $35.6 \pm 3.6$ & $27.3 \pm 1.6$ & 0.04 \\
\hline Repeat fetal intervention N (\%) & $2(20 \%)$ & $2(50 \%)$ & 0.26 \\
\hline Type of treatment & \multicolumn{2}{|l}{} \\
\hline Fetoscopic N (\%) & 10 & 4 & 0.21 \\
\hline Embolization N (\%) & 1 & 2 & \\
\hline PPROM $N(\%)$ & $1(9 \%)$ & $5(83.3 \%)$ & 0.002 \\
\hline
\end{tabular}

Abbreviations: GA, gestational age; PPROM, premature preterm rupture of membrane; SD, standard deviation. 
accomplished, further research is needed given the small number of cases in the literature. Clearly, the use of any invasive therapy requires careful consideration and will be case specific. Depending on the availability of local neonatal intensive care unit resources, preterm delivery may offer a better option in the case of a viable baby with incipient hydrops. On the other hand, in previable babies showing signs of rapid deterioration, therapy is clearly required and based on available expertise and equipment an individualized choice will need to be made. We agree with Babic et al that therapy is likely only contemplated when there are ultrasound features of fetal compromise and the gestation is previable. ${ }^{15}$ In a high resource environment with all available options, it appears that the literature favors a laser ablation procedure. The choice between interstitial laser and fetoscopic laser will be based on expertise, experience, equipment, and the location of the chorioangioma.

The interstitial laser technique requires only local anesthesia a procedure needle and ultrasound guidance, and furthermore precise placement of the needle into the feeder vessel is not mandatory. However, the results (100\% survival in four cases) should be tempered by the facts that the degree of severity of the chorioangiomas is unclear, there are a limited number of cases, and there is minimal reported experience in other centers. ${ }^{6,7}$ In our case, given that we had not previously performed an interstitial laser ablation, we were fearful that such a procedure, through an anterior placenta, near to the cord insertion, could have had unwanted ischemic or hemorrhagic complications. We elected to ablate the vessels under vision, and this appears to have been important in this case since following ablation of the major feeders we recognized that flow into and out of the chorioangioma continued. On further exploration of the lesion were able to identify several small vessels connecting the chorioangioma to vessels other than the cord insertion site, and these vessels, although of much smaller caliber, were sufficient to perfuse the tumor. The question of whether they would enlarge over time and promulgate ongoing hydrops cannot be answered here, but is at least a theoretical possibility (and perhaps an explanation of those cases where apparently successful occlusion of feeder vessels (by whatever method) fails over time.

Antenatal embolization of the feeding vessels of the chorioangioma has been reported in three cases with promising results, but the numbers are too small to draw any strong conclusions as to whether or not this can be regarded as a preferred method. ${ }^{15}$

We believe that this review indicates a need for an international registry to document management, accurately record the complications of therapy, and determine the perinatal outcomes.

Note

This study did not receive any type of financial support from any institution. Authors do not have any conflict of interest to declare.

\section{References}

1 Amer HZ, Heller DS. Chorangioma and related vascular lesions of the placenta-a review. Fetal Pediatr Pathol 2010;29(4):199-206

2 Guschmann M, Henrich W, Dudenhausen JW. Chorioangiomasnew insights into a well-known problem. II. An immuno-histochemical investigation of 136 cases. J Perinat Med 2003;31(2): 170-175

3 As AK, Hagen P, Webb JB, Wijesinghe D. Therapeutic amniodrainage in chorioangioma. J Obstet Gynaecol 1997;17(2):169-170

4 Hamill N, Rijhsinghani A, Williamson RA, Grant S. Prenatal diagnosis and management of fetal anemia secondary to a large chorioangioma. Obstet Gynecol 2003;102(5 Pt 2):1185-1188

5 Sepulveda W, Wong AE, Herrera L, Dezerega V, Devoto JC. Endoscopic laser coagulation of feeding vessels in large placental chorioangiomas: report of three cases and review of invasive treatment options. Prenat Diagn 2009;29(3):201-206

6 Zanardini C, Papageorghiou A, Bhide A, Thilaganathan B. Giant placental chorioangioma: natural history and pregnancy outcome. Ultrasound Obstet Gynecol 2010;35(3):332-336

7 Bhide A, Prefumo F, Sairam S, Carvalho J, Thilaganathan B. Ultrasound-guided interstitial laser therapy for the treatment of placental chorioangioma. Obstet Gynecol 2003;102(5 Pt 2):1189-1191

8 Lau TK, Leung TY, Yu SC, To KF, Leung TN. Prenatal treatment of chorioangioma by microcoil embolisation. BJOG 2003;110(1): $70-73$

9 Quarello E, Bernard JP, Leroy B, Ville Y. Prenatal laser treatment of a placental chorioangioma. Ultrasound Obstet Gynecol 2005;25(3): 299-301

10 Quintero RA, Reich H, Romero R, Johnson MP, Gonçalves L, Evans MI. In utero endoscopic devascularization of a large chorioangioma. Ultrasound Obstet Gynecol 1996;8(1):48-52

11 Stroup DF, Berlin JA, Morton SC, et al. Meta-analysis of observational studies in epidemiology: a proposal for reporting. Metaanalysis Of Observational Studies in Epidemiology (MOOSE) group. JAMA 2000;283(15):2008-2012

12 von Elm E, Altman DG, Egger M, Pocock SJ, Gøtzsche PC, Vandenbroucke JP; STROBE Initiative. Strengthening the Reporting of Observational Studies in Epidemiology (STROBE) statement: guidelines for reporting observational studies. BMJ 2007;335(7624):806-808

13 Mielke G, Benda N. Cardiac output and central distribution of blood flow in the human fetus. Circulation 2001;103(12): 1662-1668

14 Shamshirsaz AA, Javadian P, Ruano R, et al. Comparison between laparoscopically assisted and standard fetoscopic laser ablation in patients with anterior and posterior placentation in twin-twin transfusion syndrome: a single center study. Prenat Diagn 2015; 35(4):376-381

15 Babic I, Tulbah M, Kurdi W. Antenatal embolization of a large placental chorioangioma: a case report. J Med Case Reports 2012; 6(1):183

16 Sepulveda W, Alcalde JL, Schnapp C, Bravo M. Perinatal outcome after prenatal diagnosis of placental chorioangioma. Obstet Gynecol 2003;102(5 Pt 1):1028-1033

17 Sepulveda W, Aviles G, Carstens E, Corral E, Perez N. Prenatal diagnosis of solid placental masses: the value of color flow imaging. Ultrasound Obstet Gynecol 2000;16(6):554-558

18 Wehrens XH, Offermans JPM, Snijders M, Peeters LL. Fetal cardiovascular response to large placental chorioangiomas. J Perinat Med 2004;32(2):107-112

19 Nicolini U, Zuliani G, Caravelli E, Fogliani R, Poblete A, Roberts A. Alcohol injection: a new method of treating placental chorioangiomas. Lancet 1999;353(9165):1674-1675

20 Jauniaux E, Kadri R, Donner C, Rodesch F. Not all chorioangiomas are associated with elevated maternal serum alpha-fetoprotein. Prenat Diagn 1992;12(1):73-74

21 García-Díaz L, Carreto P, Costa-Pereira S, Antiñolo G. Prenatal management and perinatal outcome in giant placental 
chorioangioma complicated with hydrops fetalis, fetal anemia and maternal mirror syndrome. BMC Pregnancy Childbirth 2012; $12: 72$

22 Lau TK, Yu SCH, Leung TY, To KF, Fung TY, Leung TN. Prenatal embolisation of a large chorioangioma using enbucrilate. BJOG 2005;112(7):1002-1004

23 Wanapirak C, Tongsong T, Sirichotiyakul S, Chanprapaph P. Alcoholization: the choice of intrauterine treatment for chorioangioma. J Obstet Gynaecol Res 2002;28(2):71-75

24 Al Wattar BH, Hillman SC, Marton T, Foster K, Kilby MD. Placenta chorioangioma: a rare case and systematic review of literature. J Matern Fetal Neonatal Med 2014;27(10):1055-1063

25 Deren O, Ozyuncu O, Onderoglu LS, Durukan T. Alcohol injection for the intrauterine treatment of chorioangioma in a pregnancy with transfusion resistant fetal anemia: a case report. Fetal Diagn Ther 2007;22(3):203-205

26 Mendez-Figueroa H, Papanna R, Popek EJ, et al. Endoscopic laser coagulation following amnioreduction for the management of a large placental chorioangioma. Prenat Diagn 2009;29(13): 1277-1278

27 Bermúdez C, Luengas O, Pérez-Wulff J, et al. Management of a placental chorioangioma with endoscopic devascularization and intrauterine transfusions. Ultrasound Obstet Gynecol 2007;29(1): 97-98
28 Bashiri A, Maymon E, Wiznitzer A, Maor E, Mazor M. Chorioangioma of the placenta in association with early severe polyhydramnios and elevated maternal serum HCG: a case report. Eur J Obstet Gynecol 1998;79(1):103-105

29 Jauniaux E, Ogle R. Color Doppler imaging in the diagnosis and management of chorioangiomas. Ultrasound Obstet Gynecol 2000;15(6):463-467

30 Haak MC, Oosterhof H, Mouw RJ, Oepkes D, Vandenbussche FP. Pathophysiology and treatment of fetal anemia due to placental chorioangioma. Ultrasound Obstet Gynecol 1999;14(1):68-70

31 Escribano D, Galindo A, Arbués J, Puente JM, De la Fuente P. Prenatal management of placental chorioangioma: value of the middle cerebral artery peak systolic velocity. Fetal Diagn Ther 2006;21(6):489-493

32 Wang LH, Tang JR, Teng RJ, et al. Hydrops fetalis due to placental chorioangioma: report of one case. Zhonghua Min Guo Xiao Er Ke Yi Xue Hui Za Zhi 1997;38(2):155-158

33 Zalel Y, Weisz B, Gamzu R, Schiff E, Shalmon B, Achiron R. Chorioangiomas of the placenta: sonographic and Doppler flow characteristics. J Ultrasound Med 2002;21(8):909-913

34 Jones K, Tierney K, Grubbs BH, Pruetz JD, Detterich J, Chmait RH. Fetoscopic laser photocoagulation of feeding vessels to a large placental chorioangioma after fetal deterioration post amnioreduction. Fetal Diagn Ther 2012;31(3):191-195 